\title{
Rural women empowerment through small scale poultry farming: A case study of Vattamkulam model, Malappuram
}

\author{
S. L. Gayathri ${ }^{\text {a }}$ and (D) M. Muhammed Asif ${ }^{\text {b }}$ \\ ${ }^{a}$ PhD Research Scholar, Livestock Production Management Division, ICAR- National Dairy Research Institute, \\ Karnal, Haryana- 132001 \\ ${ }^{b}$ MVSc Scholar, College of Veterinary and Animal Sciences, Mannuthy, Kerala Veterinary and Animal Sciences \\ University, Pookode, Wayanad- 673576
}

Corresponding author: S. L. Gayathri| Email: gayathrisherlylal@gmail.com Co-author: MMA: asifmasifvet@gmail.com

Received: 13-10-2020, Accepted: 19-11-2020, Published online: 20-12-2020

\begin{abstract}
The Animal husbandry department of Kerala and local self-government department and Kudumbashree mission has started a plan during 2018-19 entitled "Backyard broiler farming" at Vattamkulam Gramapanchayath, Edappal, Malappuram district. The said plan was advertised as 'Earn money at your doorstep through broiler farming' and was welcomed by more than 40 household women. The farmers who owned a land area, not less than 10 cents were selected for this model. The local self- Government provided the shelter arrangements including cages for free of cost. The Animal husbandry department has supplied chicks (Day old Cobb varieties) and feed and aided Kudumbashree unit to market these broilers. The speciality of broiler farming is that within a short period (35 - 40 days) a chick gains an average weight of $2-2.3 \mathrm{~kg}$, which can be sold at market to earn a reasonable margin of profit for farmers. The usual mortality rate was $5 \%$ for broiler farming, but it was less than $2 \%$ in this model. Modified vaccination protocol against the viral disease Gumboro (I.B.D), has been adopted for this model to reduce the mortality rate. Also, antibiotics as feed additives were not supplemented in this model. Within 40 days, these women entrepreneurs are getting a good profit from meat production alone. This broiler meat is marketed under the brand name of Vattamkulam Safe Chicken. The Vattamkulam backyard broiler farming helps the household women support themselves and provide safe and quality meat to society in which they belong.
\end{abstract}

Keywords: Women empowerment, Vattamkulam Model, Broiler farming

döi: httons://doi.org/10.51128/jfas.2020.A023 1 How to cite this article: Gayathri, S. L. and Muhammed Asif, M. 2020 . Rural women empowerment through small scale poultry farming: A case study of Vattamkulam model, Malappuram. Journal of Food and Animal Sciences, 01(02): $126-130$.

Copyright: Gayathri and Muhammed Asif, 2020. Open Access. This article is distributed under the terms of the Creative Commons Attribution 4.0 International License (http://creativecommons.org/licenses/by/4.0/), which permits unrestricted use, distribution, and reproduction in any medium, provided you give appropriate credit to the original author(s) and the source, provide a link to the Creative Commons license, and indicate if changes were made. The Creative Commons Public Domain Dedication waiver (http://creativecommons.org/publicdomain/zero/1.0/) applies to the data made available in this article, unless otherwise stated. 


\section{Introduction}

The seeds of broiler farming revolution in Kerala have had germinated in Malappuram district of Kerala. Women empowerment and short scale broiler farming go hand in hand in the above-said region. The Animal husbandry department and Local selfGovernment department and Kudumbashree mission have started a plan during 2018-19 entitled "Backyard broiler farming” at Vattamkulam Gramapanchayath, Malappuram district. The said action plan has helped several household women enhance their economic viability and provide financial stability. The local self- Government have provided the necessary shelter arrangements including the cages to these women to start up the backyard broiler farming unit free of cost. The Animal husbandry department has supplied chicks (Cobb variety) and feed and aided the Kudumbashree unit in marketing these broilers. The plan which started in September 2018 has successfully finished many batches now.

The speciality of broiler farming is that within a short time (35-40 days) a chick gains an average weight of $2 \mathrm{~kg}$, which can be sold at market to earn an adequate margin of profit for farmers. For this purpose, the farmers have to choose the right strain/ varieties and provide them with adequate food both in quality and quantity. The rumours about injecting hormones to broiler chicken outstand when these facts throw light to the outer world. Generally, in rural areas, chicken reared in the backyard are generally Desi type which are low producing concerning egg and meat (Ghosh et al., 2005).

Backyard layer farming was a grant success for the Animal Husbandry department wherein several farmers adopted the layer farming mini-unit throughout Kerala. The success of which introduced the varieties of Gramalekshmi, Gramasree, BV 380 at several households. The average flock size per household differs between seasons mainly due to feed availability, the occurrence of diseases and predators (Moges et al., 2010). But this model, per unit, has had 300 chicks in number. This venture enhanced food security, though, for broiler meat, the consumers still depend on other states. The Vattamkulam backyard broiler farming is an aid to the household ladies to help themselves and provide safe and quality meat to society in which they belong. This model's success entrusts the Government to startup, such models, on an all Kerala basis to help rural women.

\section{Methodology}

Senior veterinary surgeon, Dr. V. K. P. Mohan Kumar of Vattamkulam Gramapanchayat laid the stepping stones for mini broiler unit at their area. The beginning of Vattamkulam model was his noble idea. Along with the Kudumbashree unit and the local selfGovernment department, pilot studies were carried out at the households of Vattamkulam Gramapanchayath. Amidst the odds in finding a market for the broiler chicken at local market where the other state lobbies are strong enough, the veterinarians and the authorities stood hand in hand and went ahead with the project.

The advertisement 'Earn money at your doorstep through broiler farming' advertised by the Vattamkulam Gramapanchayat was welcomed by more than 40 household women. They participated in this venture with utmost interest. The farmers who owned a land area, not less than 10 cents were selected for this project. The orientation programme was conducted for these ladies as there was lack of awareness among them by the Kudumbashree unit supported by the State Animal Husbandry department. The Panchayath officials entrusted broiler cages for 100 birds to workers of MNREGA, which was completed within 17-18 days, costing around 7000 rupees only. When all the pre-requisites for farming were optimized, the Animal Husbandry department bought chicks from the hatcheries to the broiler units. Age-old Cobb varieties were distributed among the farm-women at the rate of 100 in number/ unit. Also, $350 \mathrm{~kg}$ feed was distributed per farmer free of cost.

The Animal Husbandry Department had spent an amount of 12000 rupees per broiler unit. Classes about processing and marketing of meat, training sessions, waste disposal etc. are being carried out regularly for these farm-women until Vattamkulam Gramapanchayat. Several broiler lobbies threatened these ladies, who are new to the venture, but they survived because of their self-confidence and officials' support.

The cages for 100 birds per broiler unit were designed by the Dr V. K. P. Mohan Kumar himself. The birds were reared in deep litter system using coir pith as litter material. The usual mortality rate was $5 \%$ for broiler farming, but it was less than $2 \%$ in 

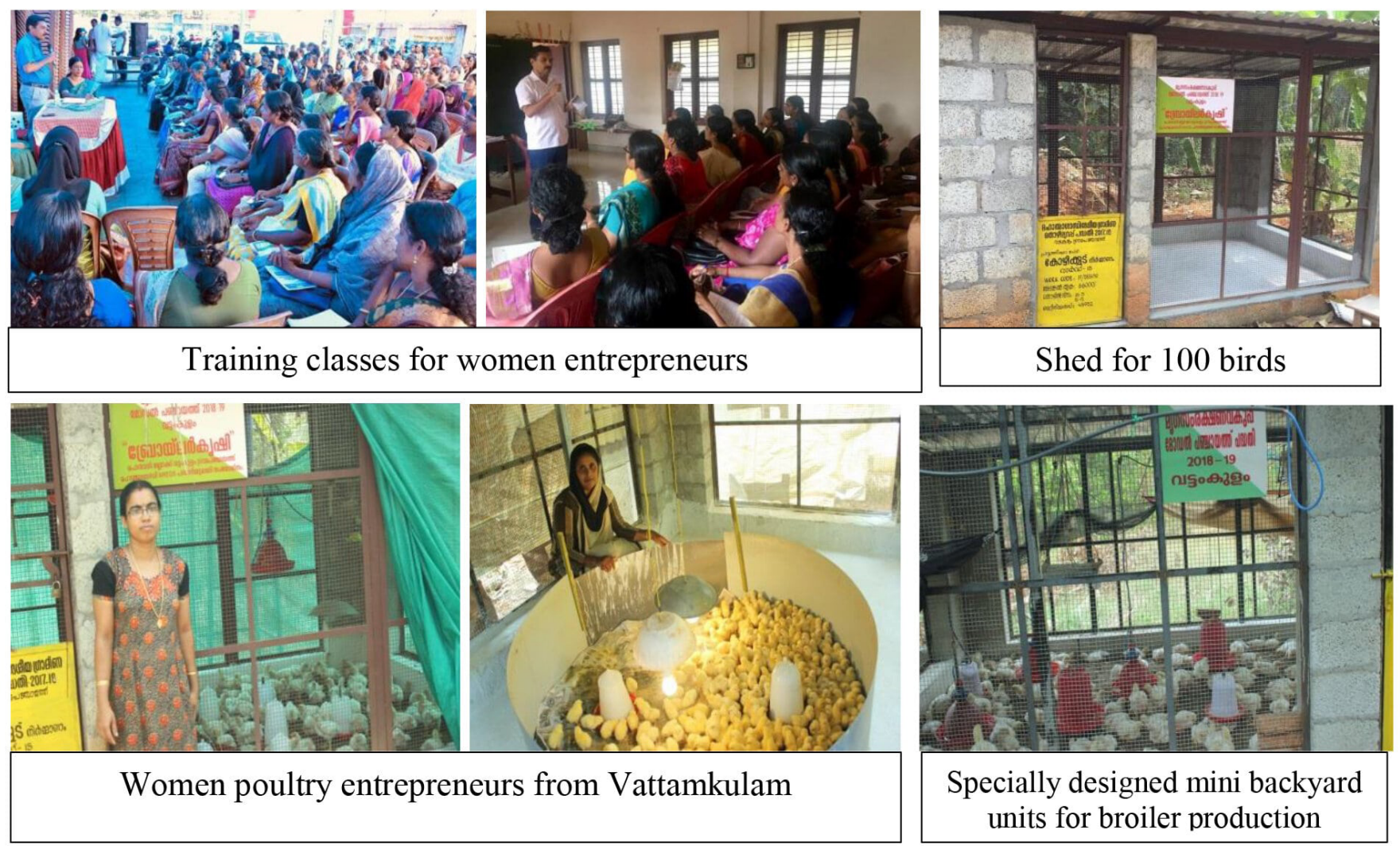

Figure 1: Vattamkulam model Backyard broiler farming

this model. Modified vaccination protocol against the virus disease Gumboro, has been developed for this model to reduce the mortality rate. The mortality rate for the said disease is $75 \%$, and vaccination against it was given on the $14^{\text {th }}$ day. In this model, vaccination was given on 14,21 and $28^{\text {th }}$ days to broiler birds against the Gumboro disease. Also, antibiotics as feed additives were not supplemented in this model.

\section{Results and Discussion}

Vattamkulam organic broiler chicken has had become a grant success. Several batches have already been marketed from each unit. Within 40 days, these women entrepreneurs were getting a fair amount from meat production alone. $1.75 \mathrm{~kg}$ weighing birds were ready within 1.5 months. Each broiler unit with 100 birds was getting nearly 5000 rupees profit. The broiler meat was marketed under the brand name of Vattamkulam Safe Chicken. It was initially difficult to find market for this organic meat, but the situation has changed and the demand has increased drastically. The Vattamkulam Chicken is sold at a higher price (10 Rupees Higher) than the other broiler chicken sold by other state lobby. Vattamkulam Swadeshi chicken is devoid of any chemical hazards and antibiotics residues, subsequently it becomes consumers' choice.

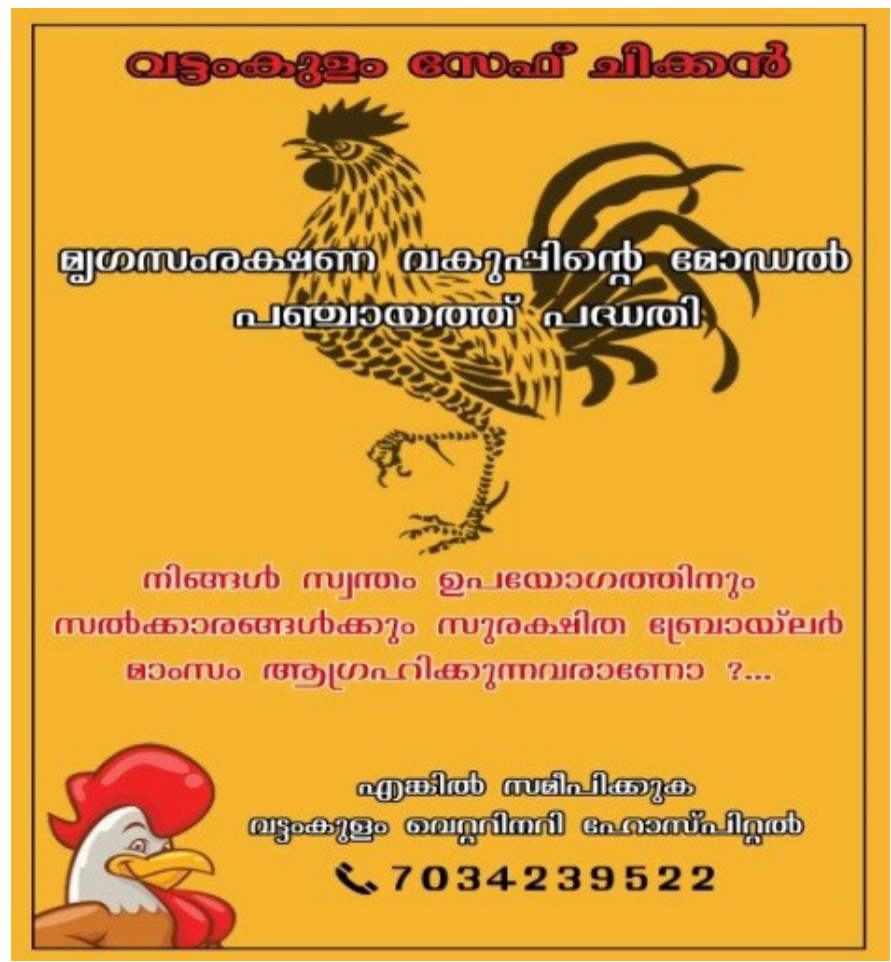

Figure 2: Vattamkulam safe chicken- Poster 


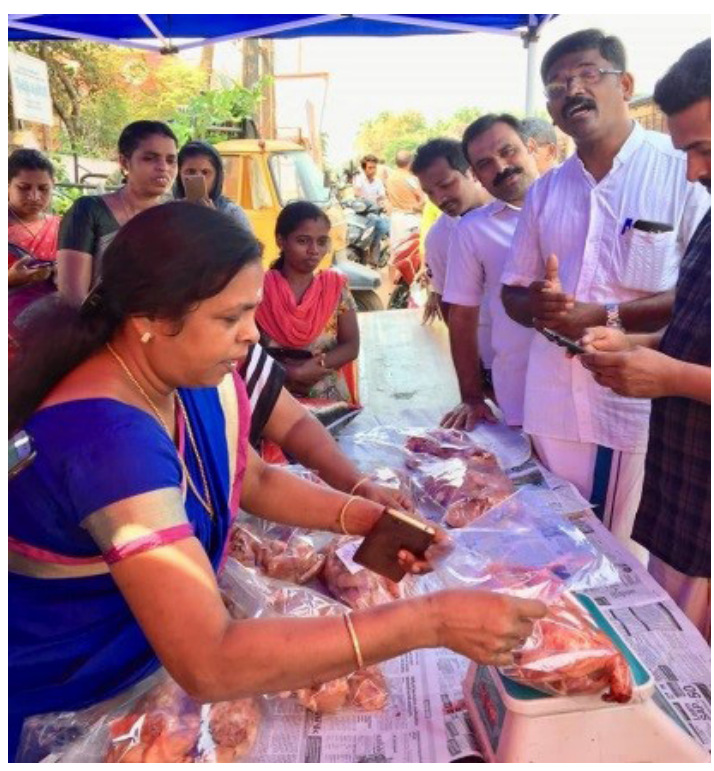

Figure 3: Vattamkulam safe chicken- Market fair conducetd by Kudumbashree units

For marketing, the organic chicken Kudumbashree has conducted fair at the adjoining city of Edapal. Several Whatsapp groups have been created for the sale of meat. The meat is not sold on a single stretch from a unit of 100 birds but sold at several steps. First marketing was done on $35^{\text {th }}$ day, selling around 20-30 birds, subsequently on $39^{\text {th }}$ and $42^{\text {nd }}$. The meat was sold in packets, which was processed and packaged at household itself. Since carcass preparation is done in the home, waste disposal is hygienic and comparatively easy. The present study agrees to the studies conducted by Aklilu, (2007) and Halima, (2007), who pointed out that women played a major role in the broiler chicken production and marketing and the profit is owned by them itself. According to Abubakar et al. (2007), village chicken production in some parts of Nigeria and Cameroon, women hold the majority of chicken (52.7\%) followed by children (26.9\%) and men (20.4\%) in Cameroon; unlike the situation in Nigeria, where the majority of the chickens are owned by men (55.6\%) followed by women (38.9\%) and children (11.1\%).

Vattamkulam is an icon of women empowerment. The success of the first batch of birds encouraged the farmers to expand their backyard unit. The Kudumbashree unit and government officials extend their full hand support to these farmers in terms of the medical facility, chick supply, marketing and technical knowledge. The Vattamkulam Gramapanchayath is known for Backyard Layer farming also. Ten years back, it started with only a few households, but now it has increased to many. Several Egg Nurseries have also been established at this Panchayat, capable of producing 1000 plus chicks at a time. The Ashraya scheme for widows was started in the year 2019, and the widows were given layer birds for backyard farming. Around 2000 widows were benefitted through the project and each widow was given 10 birds along with $10 \mathrm{~kg}$ feed per widow. Vattamkulam can be called as Keralas' Mini-Nammakal. The state Tamil Nadu is blessed to have a district called Nammakal where the poultry industry has diversified to international level. Though Vattamkulam has not reached an international fame, efforts from the Veterinary front and the government side will definitely make these farmers of this small panchayath reach up to a national level.

\section{Conclusion}

The Vattamkulam model, an icon of women empowerment, has boosted other gram panchayats to start small-scale poultry farming. Through the grand success of the said model; Animal Husbandry department is able to launch the backyard broiler farming throughout Kerala to help the women of rural households.

\section{Authorship contribution statement}

S. L. Gayathri : Conceptualization, Writing - original draft, Writing - review \& editing, M. Muhammed Asif: Writing - review \& editing.

\section{Acknowledgments}

The authors are thankful to Veterinary Hospital, Vattamkulam Gramapanchayath, Edappal, Malappuram district, Kerala, India for providing all the details regarding Vattamkulam Model

\section{Funding}

None.

\section{Declaration of Competing Interest}

All authors declare that there exist no commercial or financial relationships that could, in any way, lead to a potential conflict of interest.

\section{References}

Abubakar, M. B., Ambali, A. G. and Tamjdo, T. 2007. Rural chicken production: Effects of gender on ownership, and management responsibilities in some parts of Nigeria and Cameroon, Int. J. Poult. Sci., 6(6):413-416. 
Aklilu, H. M. 2007. Village poultry in Ethiopia; socio-technical analysis and learning with farmers $\mathrm{PhD}$ Thesis Wageningen University Wageningen the Netherlands.

Ghosh, M. K, Ahmed, F. A, Buragohain, R., Pathak, P. K. and Bhattacharya, M. 2005. Growth performance of Vanaraja birds in high altitude areas of Arunachal Pradesh under Backyard system of management. XXII Annual conference and National Symposium, Indian Poultry Science Association, Project Directorate on Poultry, Hyderabad from 2-4 February, 198.
Halima, H. 2007. Phenotypic and genetic characterization of indigenous chicken populations in northwest Ethiopia. $\mathrm{PhD}$ Dissertation University of the Free State, Bloemfontein, South Africa, 176.

Moges, F., Mellesse, A. and Dessie, T. 2010. Assessment of village chicken production system and evaluation of the productive and reproductive performance of local chicken ecotype in Bure district, North West Ethiopia. Afr. J. Agric. Res., 5:1739-1748. 